\title{
Sex and Social Class as Determinants of Future Orientation (Time Perspective) in Adolescents
}

\author{
Helinut Lamm, Rolf W. Schmidt, and Gisela Trommsdorff \\ Universität Mannheim, West Germany
}

\begin{abstract}
Hypotheses concerning the effects of sex and class on future orientation were tested on 100 boys and girls between the ages of 14 and 16. Future orientation was measured in various domains of life, constituting either private or public areas of concern (e.g., family, environment), on the dimensions of density (number of hopes and fears voiced by the subject), extension, and optimismpessimism. As predicted, middle-class adolescents, as compared with lowerclass adolescents, voiced more hopes and fears relating to public life and fewer in the private sphere, and they manifested a more extended future orientation in the private as well as the public spheres. They also judged the distant future more optimistically in two out of three public areas of concern. The lower-class girls were more optimistic than the middle-class girls in the occupational domain. As predicted, the lower-class boys voiced more hopes and fears in the occupational domain and manifested a more extended future orientation than the lower-class girls. On the other hand, the girls of both classes voiced more hopes and fears in the private sphere than the boys of either class. The results are interpreted through theories of socialization and role behavior.
\end{abstract}

Time perspective may be defined as an individual's cognitions concerning the content, placement, and unfolding of relevant events in his past, present, or future. Prior research has attempted to establish relationships between time perspective (especially as directed toward the future) and societal type (traditional vs. modern: Kluckhohn \& Strodtbeck, 1961; Mönks, 1967), social subgroups (e.g., deviance: Barndt \& Johnson, 1955; Jessor, Graves, Hanson, \& Jessor, 1968) and personality characteristics (Platt, Eisenmann, Delisser, \& Darbes, 1971; cf. also Doob, 1971).

In the body of literature just mentioned, a frequent assumption has been that social and

This research was carried out at the Sonderfor. schungsbereich 24 (Sozial- und wirtschaftspsychologische Entscheidungsforschung, Universität Mannheim) with funds from the Deutsche Forschungsgemeinschait. The data were collected and in part analyzed by Henning Eckel, who reported about them in his diplom (master's) thesis at the Universität Mannheim. The three authors have contributed equally to this article. We thank Henning Eckel for his collaboration and his discussion contributions in the earlier phases of this study. Further, we are grateful to W. A. Scott and to an anonymous reviewer for their helpful comments.

Requests for reprints should be sent to Helmut Lamm, SFB 24, Universität, 68 Mannheim, West Germany. cultural conditions affect a person's time perspective as well as his social behavior. In particular, future time perspective has been seen as a cause or correlate of the tendency or capacity to delay rewards (cf. Mischel, 1973) and of achievement motivation (cf. Heckhausen, 1967). The capacity to delay rewards in turn has been considered a precondition for social success and upward mobility, a view that has not remained unchallenged (ci. Kasakos, 1971; Nowotny, 1975).

In the present authors' view, an important though indirect contribution to the discussion about the "functional" meaning of future time perspective (e.g., its relevance for success in society) would be to investigate future time perspective empirically by taking into account a number of relevant psychological aspects or dimensions, and in particular, by including an affective component (i.e., the evaluative-emotional meaning an individual's future has for him). Thus this article focuses on some of the dimensions of future orientation and how these are influenced by sex and social class, that is, by special social roles that have become effective as a result of certain socialization experiences.

Future orientation here refers to an individual's attitude-in particular, his cognitions and feelings-toward his future. The nar- 
rower term future time perspective refers to the cognitive component (e.g., density and extension, described below) of future orientation, which is in line with its use in the relevant research literature. For the most part, the present article uses the term future time perspective when referring to literature in which this term was used.

This study includes the following aspects of future orientation (as dependent variables): (a) content-structural (density), (b) temporal-structural (extension), and (c) affective (optimism-pessimism).

The term density refers to the number of events whose occurrence a person hopes or fears in various domains of life. ${ }^{2}$ By extension we mean the length of the future time span being envisaged by a person. It is operationalized as that event which the subject places farthest in the future. This definition is identical with that of Wallace (1956, pp. $240-24 i$ ).

Optimism is defined as the positive difference between the evaluation of the future and the evaluation of the present, a negative difference (pessimism) indicating a pessimistic view of the future. This definition is in line with that of Teahan (1958, p. 38).

An additional dependent variable, termed internal-external control, is defined as a person's belief as to whether events are controlled by himself or by external forces.

A more detailed analysis of the concept of future orientation and its various dimensions can be found in Trommsdorff and Lamm (1975).

One of the first investigations of future time perspective has already dealt with its dependence upon social class as a consequence of differential socialization. LeShan (1952) investigated the effects of class-related parental reward and punishment methods, concluding that children from the lower class are more present oriented and children from the middle class are more future oriented. LeShan asked middle- and working-class children to invent stories and found that the stories of middleclass children covered a longer period of time and extended more into the future than did those of working-class children. There have been numerous challenges of this investiga- tion, and aspects of both its content and its method have been criticized.

Greene and Roberts (1961) faulted LeShan's (1952) statistical procedure and came to the conclusion that his results were not clear. Kendall and Sibley's (1970) analysis elicited the fact that the length of the stories that the children in LeShan's study had to write down had an influence on the temporal extension of those stories: The longer the story, the greater was the extension of the future time perspective. Those authors concluded that the relationship between social class and extension of future time perspective in LeShan's study was artificial. Ellis, Ellis, Mandel, Schaeffer, Sommer, and Sommer (1955) and Judson and Tuttle (1966) were not able to replicate LeShan's findings despite improved methods of statistical analysis. In contrast, Graves (cited in Lessing, 1968) reported a difference between the two social classes with regard to the extension of future time perspective, which is in line with LeShan's (1952) findings.

There are undoubtedly many reasons for the lack of clear-cut evidence on the role of social class. One of them may be the implicit assumption that the structure of the individual's future orientation (and future time perspective) is the same in all domains of life. However, Frank (1939) has already pointed out that a person can develop multiple orientations toward the future that are directed in each case toward various aspects of his private or public life, a point that has been widely disregarded in research up until now. ${ }^{2}$ One important advance that we hoped to accomplish through the present research was to obtain support for our assumption that future orientation consists of various dimensions, each of which has to be measured separately. These various dimensions-density, extension. and optimism-as well as the additional measure, perceived control, may be affected in different ways by the social attributes under investigation.

\footnotetext{
1 See Kastenbaum (1961), who limited his definition of density to the quantitative aspect.

${ }^{2}$ Lessing (1971) recently tried to distinguish between private and public future orientation.
} 


\section{Social Class and Future Orientation}

We assume that future orientation is determined by past and present experiences. Accordingly, the structure and the content of future orientation must be dependent upon the frequency (quantity) and structure of past and present relationships of interaction between the individual and his environment. In the lower class-more so than in the middle class-these relationships are characterized by many factors that together could be described as a syndrome of family orientation: nonmembership in secondary groups and organizations, helplessness and uncertainty in contact with local authorities and social institutions, and apathy in connection with events and developments in the public domain. A person of the lower class looks for and finds protection in the particularized solidarity of primary relationships within the family against a universalistically organized outside world (Oevermann, 1969; Popitz, Bahrdt, Jüres, \& Kesting, 1967). The fact of a family-centered value orientation within the lower class (Neidhardt, 1968; Rosen, 1956) can be seen as a correlate of this social withdrawal.

On the basis of these observations, it can be assumed that the members of the lower class primarily focus on private concerns in their future orientation and that persons of the middle class turn comparatively more of their attention to public concerns. Thus, we propose the following hypothesis:

Hypothesis 1: In comparison with middleclass adolescents, more of the lower-class adolescents' hopes and fears are concerned with private matters.

In his well-known study of the "achievement syndrome" Rosen (1956) showed that lower-class children have a passive, familyoriented, and present-oriented value system. In contrast, children of the upper classes were described as being active, individualistic, and future oriented, all of which are favorable prerequisites for the development of greater achievement motivation.

A large number of other findings concerning class-dependent socialization are in accord with Rosen's results. Pearlin and Kohn
(1966) showed that in comparison with the child-rearing practices of the lower class, those of the middle class are aimed more toward strengthening the self-confidence and self-responsibility of the child. In addition, with regard to the development of cognitive style (Witkin, Dyk, Faterson, Goodenough, \& Karp, 1962) and cognitive abilities (Hess \& Shipman, 1965) as well as language behavior (Bernstein, 1959; Bock, 1972; Oevermann, 1972), the socialization milieu in middleclass families is relatively better suited for developing abilities and promoting goal striving. These class-related behavioral differences are reinforced even further by secondary socialization in the school (Deutsch, 1965).

The above observations suggest that socialization practices (and learning experiences) in middle-class, more so than in lower-class, milieus are calibrated toward long-term goal setting (cf. Heckhausen, 1967), a stronger sense of control over events (cf. Lefcourt, 1972 , p. 26), and greater optimism as to the realization of one's goals.

Thus we propose the following hypotheses:

Hypothesis 2: In general, middle-class adolescents have a more widely extended future orientation (i.e., in the private as well as the public domain) than do lower-class adolescents. (This represents an attempt, with improved procedures, to replicate the findings of LeShan, 1952, and others cited.)

Hypothesis 3: Middle-class adolescents are more prone to believe that the realization of their hopes and fears depends on themselves (instead of external factors) than are lowerclass adolescents.

Hypothesis 4: Middle-class adolescents are more optimistic about their future than are lower-class adolescents.

\section{Sex and Future Orientation}

The lower the social status of a family, the more the partner relationships are oriented toward the prevailing sex role stereotypes (Lehr, 1972; Mollenhauer, 1969). The man is regarded as the "instrumental leader" of the family (Parsons, 1964) in the occupational and public domains, whereas the woman is seen as competent in the role of housewife and 
child rearer (Nyrdal \& Klein, 1956). This division of roles and abilities affects child rearing: The child is subjected to sex-specific role expectations and reinforcements (cf. Maccoby \& Jacklin, 1974). (The latter do not necessarily remain stable over the entire life span, depending on learning experiences following childhood, ef. Ahammer, 1973; the success of the Women's Movement makes this abundantly clear.)

Lehr $(1968,1969)$ reported that the career takes on a central position in (German) men's autobiographies, whereas women-even those with an occupation-mainly emphasize the events and problems of their private lives in their life portrayals. This corresponds with the observation that more girls than boys renounce or give up an occupational education in favor of an early marriage (Lessing, 1968; Myrdal \& Klein, 1956). Thus a further hypothesis of our study may be stated as follows:

Hypothesis 5: (a) Female adolescents manifest fewer occupational but more familyrelated hopes and fears than do male adolescents. (b) Female adolescents have a more extended future orientation in the family domain and a shorter one in the occupational domain.

With higher social status of parents, the sex-specific socialization patterns referred to above are less prevalent (see Lehr, 1972; Mollenhauer, 1969). Therefore, Hypothesis 5 is confined to lower-class adolescents.

\section{METHOD \\ Sample}

Subjects were 50 male and 50 female adolescents between the ages of 14 and 16 who were selected from either of two types of German schools-a "Hauptschule" or a "höhere Schule"-in a West German industrial city. (The former kind of school is the direct extension of elementary school: Pupils go through nine "classes"; after graduation the students obtain a full-time job or an apprenticeship. The latter kind of school corresponds to the United States high school, preparing pupils for a university.) Subjects participated in response to advertisements posted in the schools, in which 5 Deutsche Marks were promised per hour of participation. The lower-class sample (half of the subjects) consisted exclusively of Hauptschule students, where the head of family had solely a Hauptschule education. The middle-class sample consisted of high-school students where the head of family had completed high school or university.

\section{Design}

The first two independent variables were sex and social class, with two levels each, yielding four cells of 25 subjects. The two-fold measure of optimismpessimism (difference between present and future) prorided a third (within-subjects) factor (near vs. distant future), with two levels (in 5 years, in 20 years). The factors were all "fixed"; within-subjects measurement existed in the case of near versus distant future.

\section{Dependent Variables}

The dependent variables were measured through questionnaires that the subjects had to complete in group sessions of about three persons each.

Density. On the first page of the questionnaire the subjects listed their hopes, and on the second page, their fears. In each case the answering period was limited to 10 minutes. These raw data were categorized with the help of Cantril's (1965) scheme (agreement in $86 \%$ of the cases) by two independent judges. The original 23 categories of Cantril's scheme were reduced to 3 major categories in the private sector (family, occupation, personal development) and 3 in the public sector (economy, politics, environment). The number of listed hopes and fears in the 6 areas, divided by the total number of hopes and fears, served as the index of density. These proportions, since they were not normally distributed, were transtormed with arc $\sin \sqrt{x}$ to permit an analysis of variance (Winer, 1962, p. 221).

Extension. As a further assignment, each subject had to indicate for each of his hopes and fears how old he thought he would be at the time of the materialization of the corresponding hope or fear. The maximal difference between the subject's perceived future age and his current age for each given category (public and private domains and their subdivisions) was ther used as the index of extension. These scores were transformed with $\log x$ (to yield normal distributions) to justify analyses of variance.

Internal versus external control. Next, each subject indicated, for each of his hopes and fears, whether he thought its fulfilment depended more on himself or on extelnal factors. For this, four answer categories were provided: (a) "depends on me only," (b) "depends more on me than on chance and external circumstances," (c) "depends more on chance and external circumstances than on me," and (d) "depends on chance and external circumstances only". The proportion of hopes and fears that a subject categorized as internally controlled (Categories $a$ or $b$ ), relative to the whole number of hopes and fears, was used as his score for data analysis. This score was calculated for both the private and the public areas as well as for the total number of hopes and fears. Because of a lack of normal dis- 
tribution, these scores were transiormed with arc sin $\checkmark \bar{x}$ to permit analyses of variance.

Optimism-pessimism. On the last two pages of the questionnaire the subject had to list, for each of 10 private and 10 public areas of concern, his position "at the present," "in 5 years" (near future), and in "20 years" (distant future)." The positive extreme of the 11-point scale was 10 (best conceivable situation), its negative extreme 0 (worst conceivable situation). This was an adaptation of the aspiration ladder developed by Cantril (1965).

For the purposes of data analysis, the 20 items were condensed into three categories of the private domain (labelled family, occupation, and personal development) and three public categories (economics, politics, and environment), which in terms of content were designed to correspond roughly to the six previously mentioned areas of the density and extension variables.

The 10 "private" iterns were as follows: "my personal relations within my family," "my sexual relations," "my interpersonal contacts" (subdomain family and interpersonal relations); "my health," "my independence," "my inner satisfaction," "the realization of my real abilities" (subdomain personal development and self-actualization); "my financial situation," "my attainments in school or occupation," and "free time to practice interests not related to school or occupation" (subdomain occupation).

The 10 "public" items were as follows (all relating to West Germany, unless otherwise noted): "economic capacity" (subdomain economics); environmental pollution (subdomain environment); "relations with Eastern European countries (including East Germany)," "equal chances of education and advancement for all Germans," "criminality," "integration of Western European countries and peoples," "freedom of expression of opinion," "peace in world," "mutual belping and considerateness," and "tolerance and acceptance of minorities (e.g., foreign workers, homosexuals)" (subdomain political and social concerns).

In each of the subdomains and in the two main groups, which is equivalent to the sum oi all 10 private or public items, the mean difference between the future (near or distant) and the present was calculated. Positive differences indicated an optimistic judgment, negative differences, a pessimistic one. The distribution of these data was normal, thus permitting $2 \times 2 \times 2$ (Sex $\times$ Class $\times$ Near Versus Distant Future) analyses of variance. Near versus distant future constituted a within-subjects factor.

\section{RESULTS}

Tables 1 and 2 contain the means and standard deviations for the dependent variables and the significant results of the analyses of variance. In the case of significant interaction effects, simple-effects $F$ values were calculated (Winer, 1962, p. 174 f. and p.
340). The degrees of freedom for all listed $F$ values are 1 and 96.

\section{Results For Class}

Density. Hypothesis 1 was confirmed: The middle-class adolescents listed more (i.e., greater proportions of $)$ public $(p<.005)$ and fewer private $(p<.005)$ hopes and fears than did the lower-class adolescents. Furthermore, lower-class subjects listed more concerns in the occupational sphere than did middle-class adolescents $(p<.05)$. It should be remembered that this refers to relative measures of public and private concerns (i.e., the proportion of concerns, relative to total concerns, voiced in the respective categories).

Extension. In addition, hypothesis 2 was confirmed: Viddle-class subjects had a more extended future orientation than did the lower-class subjects in the private $(p<.005)$ as well as in the public category $(p<.005)$.

Internal versus external control. Hypothesis 3 was confirmed only in the public category, with greater internal control indicated by middle-class persons than by lower-class persons $(p<.005)$.

Optimism-pessimism. Hypothesis 4, as originally stated, was on the whole not confirmed by the data. Instead, a more differentiated statement has to be made. Middle-class adolescents judged the distant future more optimistically in the public subdomains of politics (simple-effects $F=34.41 ; p<.005$ ) and environment (simple-effects $F=12.32$; $p<.005)$ than did lower-class adolescents.

With regard to the private sphere, there was a significant $(p<.01)$ Sex $\times$ Social Class interaction in the occupational domain: For this category lower-class girls judged the future more optimistically than did middleclass girls (simple-effects $F=8.79 ; p<$ .005); this was not the case for boys.

An additional finding that may be noted here is that both class groups face the distant future with greater optimism than the near future $(p<.005$, in the private as well as public domains).

3 The 10 private items and the 10 public items correspond to the future-related concerns that were most often voiced in surveys by Lamm (Note 1) and Trommsdorif (Note 2). 


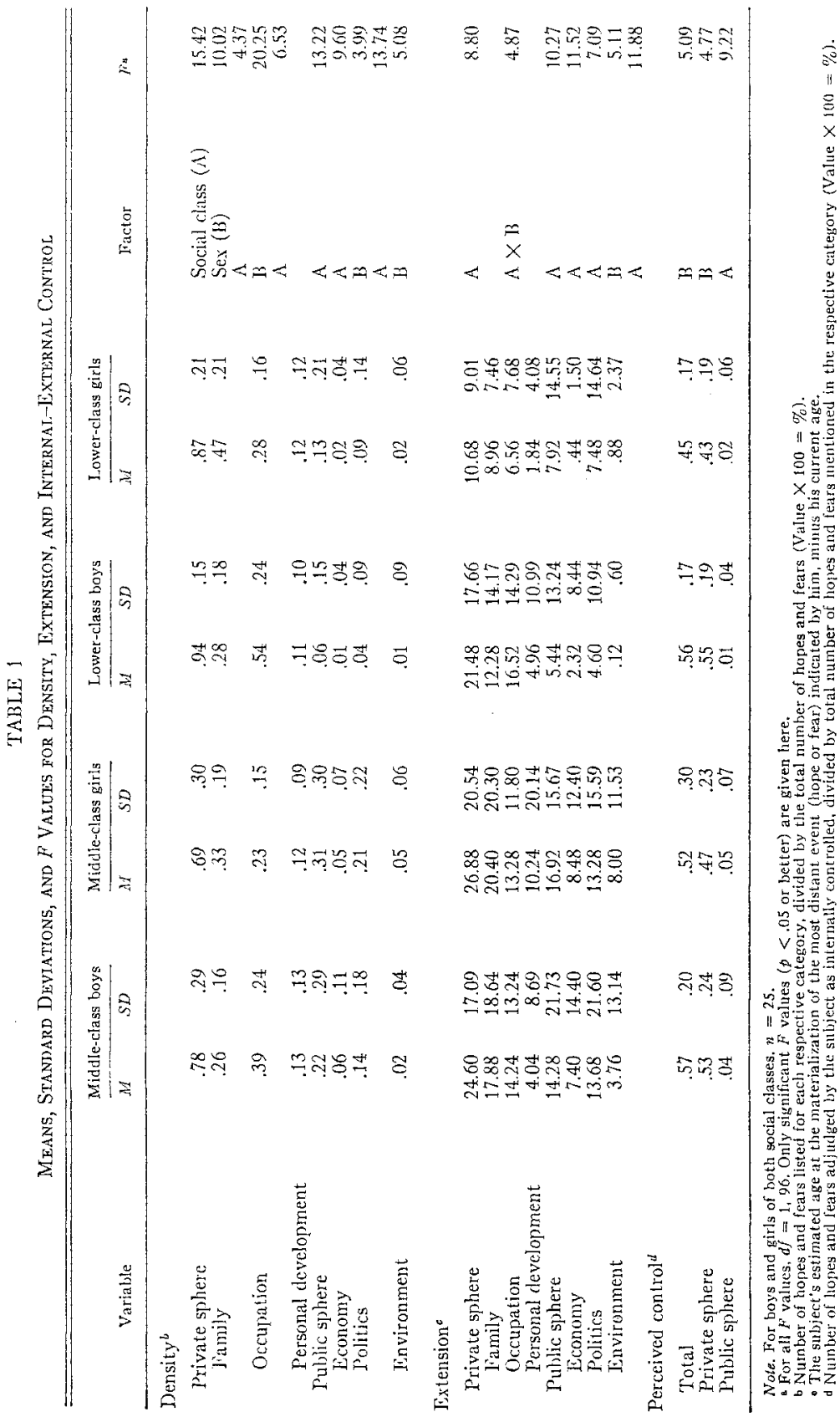




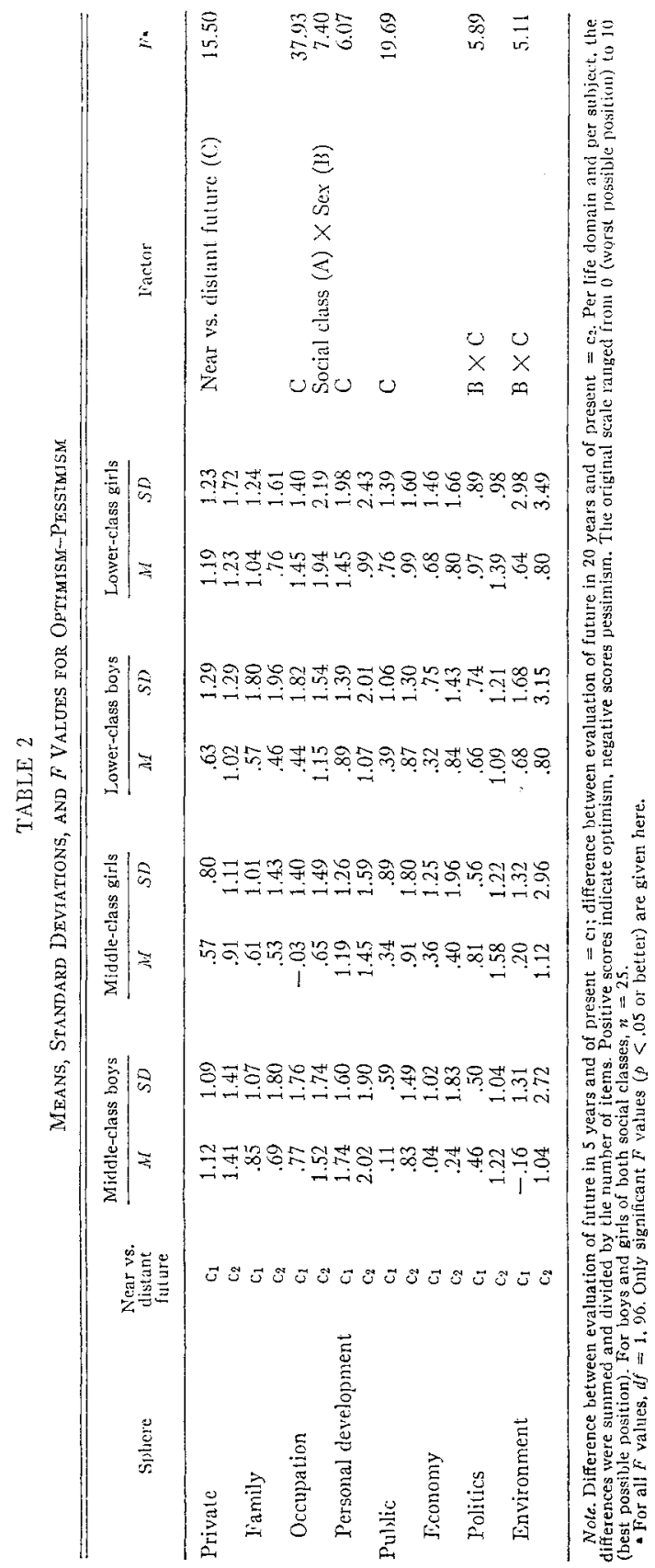




\section{Results for Sex}

Density. Hypothesis 5a was confrrmed in the occupational subdomain: Males voiced more hopes and fears than did females $(p<$ .005 ; see Table 1 ). The female adolescents of both classes voiced more hopes and fears in the private domain than did the male adolescents of both classes $(p<.005)$. Surprisingly, the females-independently of class level--voiced more hopes and fears in the public areas of politics $(p<.05)$ and environment $(p<.05)$ than did the males.

Extension. Hypothesis 5b was confirmed in the occupational area: Lower-class boys had a more extended future orientation than did lower-class girls (simple-effects $F=9.87 ; p$ $<.005$ ).

Internal versus external control. For the total of hopes and fears, males perceived more internal control than did females $(p<.05)$. This difference was also significant in the private category $(p<.05)$ but not in the public category.

Optimism-pessimism. Sex-related differences concerning optimism-pessimism were not manifested in any of the life domains, except with respect to the effect of social class (see Discussion section).

\section{Discussion}

\section{Efject of Social Class On Future Orientation}

Our hypotheses concerning the effects of social class on the three dimensions of future orientation--density, extension, and optimism-pessimism-were confirmed by these data: Middle-class adolescents are more longterm directed in their future orientation than are lower-class adolescents, and this holds for hopes and fears related to private as well as public concerns. ${ }^{*}$ In general, the middle-class adolescents are more intensively concerned with developments and processes in the public domain than are the lower-class adolescents and are more apt to believe that the materialization of their hopes and fears is dependent on themselves.

In regard to their future orientation, lowerclass adolescents mainly focus on the private sector, but even in this area their future orientation is less extended than that of their higherclass counterparts. It may well be that this shortness of time perspective is to a considerable extent responsible for the "restricted planning behavior" (Mollenhauer, 1969) of the lower class.

Effects of social class on optinism were found in the environmental and political subdomains: Middle-class persons are more optimistic but only in regard to the distant future. This lack of confirmation of our "total" hypothesis may be explained by the relatively young age of the subjects. It is likely that the influence of class on optimismpessimism becomes (more) evident at a later age. In the case of the age level tested here, the background of experience may still be relatively similar for the two classes. The amount of frustration in connection with goal striving is presumably still relatively low so that scarcely any negative changes would likely be anticipated in the (immediate) future. As they get older, lower-class persons will probably be more pervasively hampered in their goal-reaching efforts (e.g., because of lower incomes) and have more barriers to overcome than middle-class persons, with the possible consequence of greater pessimism and/or a lowering of aspirations.

A class-related difference concerning optimism, which holds only for girls, will be considered below.

\section{Infuence Of Sex Role On Future Orientation}

With respect to the lower-class adolescents, the present findings confirm earlier evidence that the training for an occupation and further education play a more important role in the plans of boys than in the plans of girls. This is shown by the fact that more of the hopes and fears of boys concern their occupation and that the future orientation of boys with respect to the occupational area is more extended. Considering the middle-class adolescents, the occupational future time per-

\footnotetext{
4 The rank-order or product-moment correlations were calculated between the dependent variables of density and extension as well as between extension and optimism-pessimism. For density versus extension, they were significant only in some areas, and for extension versus optimism-pessimism, there was no correlation within the four groups of subjects. The correlation tables are available from the authors.
} 
spective of boys is about as extended as that of girls; with respect to density, however, boys again concentrate more on the occupational domain than do girls (main effect of sex role).

What has not been hypothesized is an interaction between sex and social class with regard to the occupational future: Lower-class girls (but not boys) are more optimistic than their (same-sex) middle-class counterparts ( $p$ $<.005)$. It is possible that the latter are more realistic in their assessment of the barriers that stand in the way of a woman's taking up and practicing an occupation. An alternative interpretation is that possibly middle-class girls have higher aspirations than lower-class girls: They might consider occupations that are more difficult to prepare for, enter, and/or succeed in. Here again, the greater pessimism of middle-class girls would represent a realistic assessment of future possibilities. ${ }^{5}$

As noted above, in the occupational domain girls voice fewer hopes and fears than boys, whereas in the family domain girls voice more hopes and fears than boys. Apparently, based on the traditional distribution of roles and abilities, the family is still the domain in which the woman takes (or is compelled to take) the leading role. This offers a second possible explanation for the comparatively pessimistic attitude of middle-class girls toward developments in the occupational area: On the one hand, they make an effort toward pursuing an occupation, while on the other hand, they realize that in the end, they will still be held responsible for household and children. This anticipation of a double load may have a negative influence on their assessment of their career chances.

\section{Concluding Conments}

The findings reported above are based on a (West) German sample. We have interpreted them by means of reference to empirical and theoretical analyses from North American and German research literature. However, caution should be exercised regarding the cross-cultural validity of the present

\footnotetext{
5 We are indebted to an anonymous reviswer for suggesting this possibility.
}

findings as well as of the theoretical analyses reierred to above. The same socioeconomic group may be characterized by different typical socialization patterns for Society (Country) A in comparison with Society (Country) $B$; if these socialization patterns are causal to future orientation (or some dimension or correlate of it), then different empirical relationships may be expected for the two societies. Thus, even in two countries that are relatively close in their cultural outlook such as West Germany and the Lnited States, there is a fair possibility that the sex-related findings of the present study would not hold for Cnited States adolescents, given the earlier and, presumably, more powerful impact of the Women's Movement in the United States.

\section{REFERENCE NOTES}

1. Lamm, H. Unpublished data, Universität Mannheirn, 1969.

2. Trommsdorff, G. Unpublished data, Universität Mannheim, $1 \%$ \%

\section{REFERENCES}

Ahammer, I. M. Social learning theory as a framework for the study of adult personality development. In P. B. Baltes \& K. W. Schaie (Eds.), Life-span developmental psychology. New York: Academic Press, 1973.

Barndt, R. J., \& Johnson, D. M. Time orientation in delinquents. Journal of Abnormal and Social Psychology, 1955, 51, 343-345.

Bernstein, B. Sozio-kulturelle Determinanten des Lernens. Mit besonderer Berücksichtigung der Rolle der Sprache. Kölner Zeitschrifi für Soziologie und Sozialpsychologie, 1959, Sonderheft 4, 52-79.

Bock, I. Das Phänomen der schichtenspezifischen Sprache als pädagogisches Problem. Darmstadt: Wissenschaftliche Buchgesellschaft, 1972.

Bourdieu, P. La société traditionelle, attitude à l'égard du temps et conduite économique. Sociologie du Travail, 1963, 1, 24-44.

Cantril, $H$. The pattern of human concerns. New Brunswick, N.J.: Rutgers University Press, 1965.

Deutsch, $M$. The role of social class in language development and cognition. In A. H. Passow, M. Goldberg, \& A. J. Tannenbaum (Eds.), Education of the disadvantaged. New York: Holt, Rinehart \& Winston, 1965

Doob, I. W. Patterning of time. New Haven, Conn.: Yale University Press, 1971.

Ellis, L. M., Ellis, R., Mandel, E. D., Schaeffer, M. S., Sommer, G., \& Sommer, G. Time orientation and social class: An experimental supplement. Journal of Abromal and Social Psychology, $1955,51,146-147$. 
Frank, L. K. Time perspectives. Joutnal of Social Philosophy, 1939, 4, 293-312.

Greene, J. E., \& Roberts, A. H. Time orientation and social class: A correction. Joumal of Abnomal and Social Psychology, 1961, 62, 141.

Hechhausen, $\mathrm{H}$. The anatomy of achievement moitvation. New York: Academic Press, 1967.

Hess, R. D., \& Shipman, V. Early experience and the socialization of cognitive modes in children. Child Development, 1965, 36, 869-886.

Jessor, R., Graves, Th. D., Hanson, R. C., \& Jessor, S. L. Society, personality, and deviant behavior. New York: Holt, Rinehart \& Winston, 1968.

Judson, A. J,, \& Tuttle, C. E. Time perspective and social class. Perceptual and Motor Skills, 1966, 23, 1074.

Kasatos, G. Zeitperspektive, Planungsverhalten und Sozialisaition: Uberblick über internationale Forschungsergebnisse. München: Juventa, 1971.

Kastenbaum, R. The dimensions of future time perspective, an experimental analysis. Joumal of General Psychology, 1961, 65, 203-218.

Kendall, M. B., \& Sibley, R. F. Social class differences in time orientation: Artifact? Journal of Social Psychology, 1970, 82, 187-191.

Kluckhohn, F. R., \& Strodtbeck, F. L. Variations in vaiue orientations. Evanston, IHI.: Row, Peterson, 1961.

Lefcourt, H. Recent developments in the study of locus of control. In B. A. Maher (Ed.), Progress in experimental personality research (Vol. 6). New York: Academic Press, 1972.

Lehr, U. Veränderungen der Daseinsthematik der Frau im Erwachsenenalter. In $\mathrm{H}$. Thomae \& U. Lehr (Eds.), Altern: Probleme und Tatsachen. Frankfurt: Akademische Verlagsgesellschaft, 1968.

Lehr, U. Die Frau im Beruf. Frankfurt: Athenäum, 1969.

Lebr, U. Das Problem der Sozialisation geschlechtsspezifischer Verhaltensweisen. In C. F. Graumann (Ed.), Handbuch der Psychologie, Band 7, 2. Halbband. Göttingen: Hogrefe, 1972.

LeShan, L. L. Time orientation and social class. Journal of Abnormal and Social Psychology, 1952, $47,589-592$.

Lessing, E. E. Demographic, developmental and personality correlates of length of future time perspective. Journal of Personality, 1968, 36, 193-201.

Lessing, E. E. Comparative extension of persona] and social political future time perspective. Percepiual and Motor Skills, 1971, 33, 415-422.

Lewin, K. Field theory in social science. New York: Harper, 1951.

Maccoby, E. E., \& Jacklin, C. N. The psychology of sex differences. Stanford, Calif,: Stanford University Press, 1974.

Mischel, W. Toward a cognitive social learning reconceptualization of personality. Psychological Reviev, $1973,80,252-283$.
Mollenhauer, K. Sozialisation und Schuleriolg. In H. Roth (Ed.), Begabung und Lemen. Stuttgart: Klett, 1969.

Mönks, F. J. Sammetreferat: Zeitperspelive als psychologische Variable. Archiv für die gesamte Psychologie, 1967, 119, 131-161.

Myrdal, A., \& Klein, V. Women's two roles: Home and work. London: Routledge \& Kegan, 1956.

Neidhardt, F. Schichtspezinssche Elterneinflïsse im SozialisationsprazeB. In G. Wurzbacher (Ed.), Die Familie als Sozialisationsjaktor. Der Mensch als soziales und personales Wesen. III. Stuttgart: Enke, 1968.

Nowotny, H. Time structuring and time measurement: On the interaction between timekeepers and social time. In J. T. Fraser \& N. Lawrence (Eds.), The study of time II. New York: Springer, 1975.

Oevermann, U. Schichtenspezifische Formen des Sprachverhaltens und ihr Einfuß auf die kognitiven Prozesse. In H. Roth (Ed.), Begabung und Lernen. Stuttgart: Klett, 1969.

Oevermann, U. Sprache und soziale Herkunft (2nd ed.). Frankfurt: Suhrkamp, 1972.

Parsons, T. Das Inzesttabu in seiner Beziehung zur Sozialstruktur und zur Sozialisierung des Kindes. In T. Parsons (Ed.), Soziologische Theorie. Neuwied: Luchterhand, 1964.

Pearlin, L. J., \& Kohn, N. I. Social class, occupation, and parental values: A cross-national study. American Sociological Review, 1966, 31, 466-479.

Platt, J. J., Eisenmann, R., Dellisser, O., \& Darbes, A. Temporal perspective as a personality dimension in college students: A re-evaluation. Perceptual and Motor Skills, 1971, 33, 103-109.

Popitz, H., Bahrdt, H. P., Jüres, E. A., \& Kesting, H. Das Gesellschaftsbild des Arbeiters (3rd ed.). Tübingen: Mohr (Siebeck), 1967.

Rosen, B. C. The achievement syndrome: A psychocultural dimension of social stratification. American Sociological Review, 1956, 21, 203-211.

Teahan, J. E. Future time perspective, optimism, and academic acbievement. Journal of Abnormal and Social Psychology, 1958, 57, 379--380.

Trommsdorff, G., \& Lamm, H. An analysis of future orientation and some of its social determinants. In J. T. Fraser \& N. Lawrence (Eds.), The study of time II. Heidelberg/New York: Springer, 1975.

Wallace, M. Future time perspective in schizophrenia. Journal of Abnormal and Social Psychology, 1956, $52,240-245$.

Winer, B. J. Statistical principles in experimental design. New York: McGraw-Hill, 1962.

Witkin, H. A., Dyk, R. B., Faterson, H., Goodenough, D. R., \& Karp, S. A. Psychological differentiation: Studies of development. New York: Wiley, 1962. 